INTEGRITAS : Jurnal Pengabdian

Vol 4, No 2, Desember 2020

ISSN 2580 - 7978 (cetak) ISSN 2615 - 0794 (online)

\title{
PENGEMBANGAN DESTINASI WISATA MELALUI PELATIHAN BAHASA INGGRIS PELAKU USAHA DI KAMPUNG BLEKOK KABUPATEN SITUBONDO
}

\section{DEVELOPMENT OF TOURISM DESTINATION THROUGH ENGLISH TRAINING FOR BUSINESS OWNER IN BLEKOK VILLAGE, SITUBONDO DISTRICT}

\author{
Ratih Kesuma Dewi ${ }^{1)}$, Ach. Munawi Husein ${ }^{2)}$ \\ ${ }^{1,2}$ FKIP, Universitas Abdurachman Saleh Situbondo \\ ${ }^{1}$ Email: ratih.kesdewi@gmail.com
}

\begin{abstract}
Abstrak : Desa Klatakan terletak di kecamatan Kendit, kabupaten Situbondo. Kondisi wilayah yang strategis di pantai pantura dan adanya spesies khas burung Blekok dikawasan tersebut sebagai modal utama warga mengembangkan potensi tersebut sebagai destinasi wisata. Pada perkembangannya, Wisata Desa Kampung Blekok, dikunjungi wisatawan lokal, nasional dan mancanegara, maka dari itu kemampuan komunikasi yang baik, dapat meningkatkan kunjungan wisatawan, terutama mancanegara. Berdasarkan hasil wawancara dengan ketua Kelompok Sadar Wisata Desa Klatakan diperoleh informasi bahwa para pemuda karang taruna yang ada didesa Klatakan bertugas sebagai kru pemandu wisata (pramuwisata) belum mampu berkomunikasi menggunakan Bahasa Inggris dengan lancar. Bahkan sebagian dari mereka merasa menyerah dan tidak berminat untuk belajar Bahasa Inggris. Kondisi dan persepsi ini menimbulkan permasalahan bagi Desa Wisata Kampung Blekok. Maka, inisiatif untuk mengadakan pelatihan dan pendampingan secara berkala dilakukan sebagai upaya peningkatan kemampuan komunikasi pelaku usaha dan pengelola desa wisata kampung Blekok.
\end{abstract}

Kata Kunci: Desa wisata, Kampung Blekok, Pelatihan Bahasa Inggris

Abstract: Klatakan village is located in Kendit sub-district, Situbondo district. The strategic condition of the area on the coast of the coast and the presence of species specifically Blekok birds in this area as the main capital of residents to develop this potential as a tourist destination. In its development, Blekok tourism village, local, foreign and national tourists, therefore can have good communication, can increase tourist visits, especially foreign tourists. Based on the results of interviews with the head of the Klatakan Village Tourism Awareness Group, information about youths in the Klatakan village was asked as a tour guide crew (guides) who were not yet able to use English for free. Most of them deserved to stop and were not interested in learning English. Blekok Village and Village. Thus, assistance for training and assistance is carried out to improve communication motivation and assistance in Blekok tourism villages.

Keyword: Tourist village, Kampung Blekok, English Language Training

\section{PENDAHULUAN}

Sebagai sebuah Desa Wisata, Desa Wisata Kampung Blekok terus melakukan pembenahan dan perbaikan kualitas sumber daya masyarakat serta menggali potensi desa yang dapat dikembangkan dengan dana swadaya 


\section{INTEGRITAS : Jurnal Pengabdian}

Vol 4, No 2, Desember 2020

ISSN 2580 - 7978 (cetak) ISSN 2615 - 0794 (online)

masyarakat sendiri. Karena dana bersumber dari dana swadaya masyarakat maka banyak keterbatasan pelaksanaan kegiatan pengembangan. Hal ini sangat tidak mendukung kondisi dari Desa Wisata Kampung Blekok yang kini telah mulai berkembang yang tidak hanya diminati oleh wisatawan lokal saja tetapi juga diminati oleh wisatawan mancanegara.

Berdasarkan hasil wawancara dengan ketua Kelompok Sadar Wisata Desa Klatakan diperoleh informasi bahwa untuk memberikan pelayanan pemanduan wisata mancanegara, para pemuda karang taruna yang ada didesa Klatakan bertugas sebagai kru pemandu wisata (pramuwisata) belum mampu berkomunikasi menggunakan Bahasa Inggris dengan baik dan lancar. Bahkan sebagian dari mereka merasa menyerah dan tidak berminat untuk belajar Bahasa Inggris karena menurut mereka Bahasa Inggris itu susah dan mereka merasa bahwa mereka sudah tidak perlu lagi untuk belajar Bahasa Inggris.

Kondisi dan persepsi ini menimbulkan permasalahan bagi Desa Wisata Kampung Blekok. Potensi wisata alam dan pertanian didesa ini berpotensi untuk berkembang dan banyak diminati wisatawan lokal dan mancanegara untuk itu perlu untuk mengubah pola pikir dan sikap anti pati terhadap perubahan. Para pemuda yang berada di desa ini dan tergabung dalam Kelompok Sadar Wisata Desa Kampung Blekok harus merubah pola pikir dan segera mendapatkan pelatihan dan pendampingan untuk meningkatkan kemampuan berkomunikasi menggunakan Bahasa Inggris sebagai bekal menyambut datangnya para wisatawan mancanegara yang datang ke desa ini.

Pelatihan bahasa Inggris yang diberikan adalah ESP (English for Specific Purposes), yaitu suatu pendekatan pembelajaran Bahasa Inggris yang mengajarkan materi sesuai dengan tujuan dari seseorang untuk belajar Bahasa Inggris (Hutchinson and Waters, 1987). Pembelajaran Bahasa Inggris di Kampung Blekok akan disesuaikan dengan tugas yang diberikan kepada para pemuda yaitu menjadi pemandu wisata, maka pembelajaran Bahasa Inggris yang di rancanag adalah untuk meningkatkan kemampuan berbahasa Inggris dasar untuk menjadi seorang pemandu wisata karena pemuda-pemuda ini mempunyai peran yang 


\section{INTEGRITAS : Jurnal Pengabdian}

Vol 4, No 2, Desember 2020

ISSN 2580 - 7978 (cetak) ISSN 2615 - 0794 (online)

sangat besar terhadap keberlanjutan dan perkembangan Desa Wisata Kampung Blekok.

Kegitan-kegiata pembelajaran dirancang untuk meningkatkan penguasaan kosakata dibidang wisata alam dan pertanian dan mempraktekkan keterampilan berbicara dengan menerapkan strategi pembelajaran kooperatif dan kegiatan pembelajaran dalam bentuk demonstrasi, simulasi, kerja kelompok dan diskusi.

Adapun tujuan dari pelatihan dan pendampingan penguasaan Bahasa Inggris adalah :

1. Memberikan sosialisasi dan motivasi tentang pentingnya menguasai kemampuan Bahasa Inggris bagi pengelola dan pelaku usaha di desa wisata kampung Blekok, terutama anggota kru pemandu wisata untuk belajar Bahasa Inggris yang sangat bermanfaat dalam memberikan pelayanan pemandu wisata khususnya wisatawan mancanegera yang datang ke Desa Wisata Kampung Blekok.

2. Memberikan pelatihan Bahasa Inggris kepada para pemuda secara intensif yang menitikberatkan pada penguasaan keterampilan berbicara (speaking) untuk memandu wisatawan mancanegara.

\section{METODE PELAKSANAAN}

Kegiatan pengabdian kepada masyarakat ini dilakukan melalui beberapa tahapan yang dirancang dan dibuat agar kegiataan program pengabdian berjalan dengan efektif dan tepat sasaran.Tahapan kegiatan tersebut meliputi persiapan, perumusan masalah, pelaksanaan yang meliputi Sosialisasi, Pelatihan dan Pendampingan dan evaluasi program. Alur kegiatan pengabdian diilustrasikan sebagai berikut.

Tahap awal dari kegiatan ini adalah tahap persiapan. Dalam tahapan ini dilakukan survei ke lokasi mitra. Di lokasi mitra, Tim pelaksanan kegiatan melakukan pengamatan untuk melihat situasi dan kondisi mitra serta mengidentifikasi permasalahan yang dihadapi mitra. Semua data dan informasi yang diperoleh dari lokasi mitra kemudian dianalisa sebagai dasar untuk merumuskan strategi atau langkah-langah kongkrit untuk menentukan prioritas 


\section{INTEGRITAS : Jurnal Pengabdian}

Vol 4, No 2, Desember 2020

ISSN 2580 - 7978 (cetak) ISSN 2615 - 0794 (online)

masalah dan cara mengatasi masalah yang dihadapi mitra. Dari hasil kajian informasi dan data serta diskusi dengan mitra yang diperoleh pada tahap persiapan, maka dapatlah dirumuskan permasalahan yang sedang di hadapi mitra adalah rendahnya motivasi dari para pemuda karang taruna di Desa Klatakan untuk belajar bahasa Inggris sebagai bekal mereka sebagai pramuwisata di Desa Wisata Kampung Blekok dalam rangka memberikan pelayanan bagi wisatawan mancanegara yang datang ke Desa Wisata Kampung Blekok.

Untuk membantu mitra menyelesaikan permasalahan yang dihadapi tersebut, maka tim pelaksana pengabdian merancang pelatihan Bahasa Inggris yang berupa pelatihan Bahasa Inggris dengan merancang pelatihan dengan seksama melalui beberapa prosedur yang dilakukan. Tahap pertama adalah menentukan tujuan pembelajaran (Learning Objectives).Tujuan pembelajaran Bahasa Inggris di desa Wisata Kampung Blekok adalah untuk Peserta pelatihan adalah untuk melakukan komunikasi Bahasa Inggris dasar sebagai pramuwista lokal. Tahap kedua adalah menentukan keterampilan Bahasa (language skills).

Keterampilan Bahasa untuk dapat mencapai tujuan pembelajaran sebagai seorang pramuwista lokal adalah keterampilan berbicara (speaking) dengan tidak mengindahkan keterampilan Bahasa yang lainnya yaitu membaca (reading), menulis (writing) dan mendengarkan (listening) yang harus diajarkan untuk mencapai tujuan pembelajaran yang telah ditetapkan. Langkah ketiga adalah menentukan metode pembelajran yang sesuai untuk menciptakan suasana kelas yang interaktif dengan kegiatan-kegiatan pembelajaran. Metode pembelajaran yang diterapkan dalam pelatihan ini adalah pembelajaran Kooperatif Coopertaive Learning) yang menitikberatkan pada siswa (student-centered) dengan kegiatan pembelajaran yang berupa bermain peran (role play), diskusi dalam kelompok kecil (small- group discussion), bekerja secara berpasangan (pair-work), dan presentasi (presentation).

Tahap kedua adalah tahap pelaksanaan kegiatan pengabdian. Pada tahapan ini yang pertama dilakukan adalah memberikan sosialisasi tetang pentingnya 


\section{INTEGRITAS : Jurnal Pengabdian}

Vol 4, No 2, Desember 2020

ISSN 2580 - 7978 (cetak) ISSN 2615 - 0794 (online)

menguasai bahasa asing khususnya yang diberikan oleh tim pelaksana kegiatan di balai desa Klatakan.

Kegiatan berikutnya adalah pelatihan bahasa Inggris yang dilakukan mulai selama empat pertemuan. Pelatihan Bahasa Inggris diberikan kepada para pemuda desa untuk mampu berkomunikasi Bahasa inggris dasar untuk menguasai keterampilan berbicara (speaking) sebagai pramuwisata (guide). Pelatihan ini dilakukan oleh tim pelaksana kegiatan pengabdian dan dibantu dengan salah satu dosen dari Program Studi keguruan dan ilmu kependidikan yang mempunyai kemampuan Bahasa Inggris cukup bagus dan mempunyai kesabaran dan ketelitian untuk mendampingi peserta pelatihan dalam praktek berkomunikasi menggunakan Bahasa Inggris. Metode pembelajaran yang dilakukan adalah pembelajaran kooperatif (cooperative learning).

Pembelajaraan kooperatif (cooperative learning) adalah sebuah strategi pembelajaran yang menekankan pada peran aktif peserta didik dalam proses pembelajaran. Kegiatan pembelajaran dirancang untuk membuat para peserta didik melakukan kegiatan dalam kelompok-kelompok kecil saling bekerjasama antar anggota kelompok untuk mencapai tujuan pembelajaran. Model pembelajaran kooperatif dapat pula didefinisikan sebagai model pembelajaran terstruktur yang memiliki lima unsur pokok (Johnson \& Johnson, 1993) yaitu saling ketergantungan positif, tanggung jawab individual, interaksi personal, keahlian bekerjasama, dan proses kelompok.

Peserta pelatihan adalah para pemuda Karang Taruna di Desa Klatakan yang berjumlah 8 orang. Pelatihan diberikan sebanyak 4 pertemuan dengan 7 tema atau materi. Pelatihan dilakukan di pendopo yang ada di desa tersebut. Materi-materi tersebut adalah:

1. Greeting and Introducing

2. Giving information about places of interest

3. Asking and answering required questions.

4. Describing Objects dan giving instructions

5. Explaining Safety, Rules and Etiquette 


\section{INTEGRITAS : Jurnal Pengabdian}

Vol 4, No 2, Desember 2020

ISSN 2580 - 7978 (cetak) ISSN 2615 - 0794 (online)

6. Asking about and giving directions

7. Explaining the procedure of making handicraft.

\section{HASIL DAN PEMBAHASAN}

Kegiatan Kegiatan pengabdian yang dilakukan di desa mitra yaitu Desa Wisata Kampong Blekok dengan khalayak sasaran para pemuda karang taruna yang ada di desa Wisata Kampung Blekok menghasilkan pemahaman yang baik bagi para pemuda karang taruna terhadap peran penting penguasaan keterampilan berkomunikasi menggunakan Bahasa Inggris bagi pengelola wisata. Disamping itu, melalui kegiatan pelatihan ini para pemuda juga berhasil meningkatkan keterampilan mereka untuk berkomunikasi menggunakan Bahasa Inggris.

Pelatihan Bahasa Inggris yang diberikan kepada para pemuda karang taruna di Desa Wisata Kampung Blekok menunjukkan peningkatan kemampuan dalam melakukan komunikasi dasar menggunakan Bahasa Inggris. Peningkatan ini dilihat dari perubahan yang terjadi dengan membandingkan hasil wawancara pada pertemuan pertama pelatihan dengan hasil wawancara yang dilakukan diakhir pelatihan. Pada pertemuan pertama diperoleh data bahwa rata-rata peserta pelatihan hanya mampu memperkenalkan diri dengan menyebutkan nama, umur, dan pekerjaan saja. Secara umum peserta pelatihan belum mampu melakukan beberapa hal diantaranya:

1. Tidak merespon pertanyaan yang diajukan oleh tim dengan tepat dan lancar.

2. Tidak mampu menyusun kalimat sederhana yang terdiri dari subyek dan predikat dengan tepat.

3. Tidak mempunyai perbendaharaan kata yang cukup tentang pertanian, perkebunan dan perikanan.

4. Tidak mempunyai rasa percaya diri untuk berbicara karena takut salah.

Setelah diadakan pelatihan, peserta didik menunjukkan peningkatan kemampuan dan keterampilan dalam berbicara. Peningkatan yang sangat besar dapat dilihat bahwa peserta didik:

1. Mampu membuat kalimat sederhana dan mengucapkannya dengan tepat dan akurat. 


\section{INTEGRITAS : Jurnal Pengabdian}

Vol 4, No 2, Desember 2020

ISSN $2580-7978$ (cetak) ISSN 2615 - 0794 (online)

2. Mampu membuat kalimat tanya dan menjawab pertanyaan dengan tepat dan lancar.

3. Tidak merasa malu dalam mengucapkan kalimat sederhana, mengajukan pendapat, dan menyampaikan gagasan.

4. Menguasai kosakata tentang pertanian, perkebunan dan perikanan ynag diberikan.

Selama pelaksanaan kegiatan, tim pelaksana kegiatan melakukan evaluasi proses (on-going evaluation) terhadap pelaksanaan program dilapangan. Dari kegiatan ini diperoleh hasil bahwa materi yang disusun sudah sesuai dengan tingkat kemampuan peserta didik namun tetap dibutuhkan pendampingan dalam menyelesaikan kegiatan pembelajaran. Disamping itu, sampai pertemuan kedua masing ditemukan mahasiswa yang takut berbicara karena takut membuat kesalahan dalam pengucapan dan masih malu-malu untuk berbicara menggunakan Bahasa Inggris. Pada pertemuan ke tiga sampai akhir pelatihan semua peseta pelatihan sudah tidak lagi malu-malu dan takut untuk berbicara menggunakan bahasa Inggris.
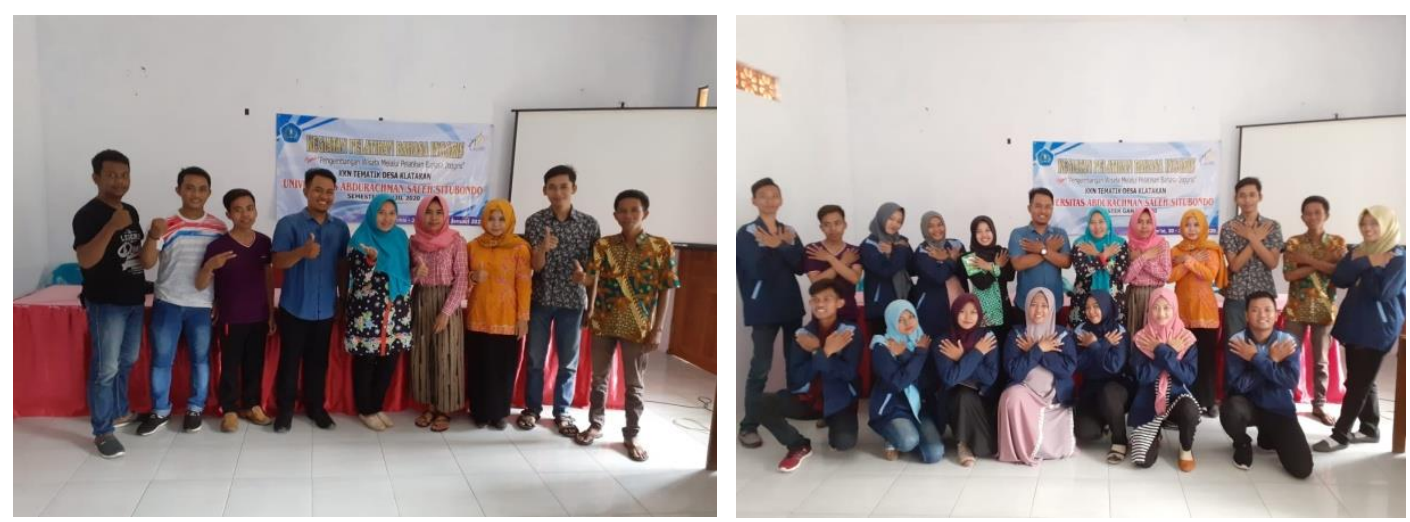

Gambar 1.

Narasumber dan Pengelola Desa Wisata setelah kegiatan Pelatihan

Dari keseluruhan rangkaian kegiatan pengabdian, tim pelaksana kegiatan melakukan evaluasi akhir (final evaluation) terhadap keberhasilan program. Tim pelaksana kegiatan melakukan diskusi dengan ketua kelompok sadar wisata. 


\section{INTEGRITAS : Jurnal Pengabdian}

Vol 4, No 2, Desember 2020

ISSN 2580 - 7978 (cetak) ISSN 2615 - 0794 (online)

Beliau menyatakan sangat puas dengan hasil pelatihan ini. Beliau berharap ada keberlanjutan kegiatan serupa untuk semakin meningkatkan keterampilan berbicara para kru pramuwisata yang ada di Desa Wisata Kampung Blekok.

\section{KESIMPULAN}

Pemuda-pemuda ini mempunyai peran yang sangat besar terhadap keberlanjutan dan perkembangan desa wisata kampung Blekok, oleh karena itu semangat dan motivasi yang baik adalah potensi besar untuk membangkitkan Desa Wisata Kampung Blekok, lebih baik lagi.

Dari keseluruhan rangkaian kegiatan pengabdian, tim pelaksana kegiatan melakukan evaluasi akhir (final evaluation) terhadap keberhasilan program. Tim pelaksana kegiatan melakukan diskusi dengan ketua Kelompok sadar wisata maka didapatkan hasil bahwa pengelola dan pelaku usaha menjadi termotivasi untuk belajar lebih lanjut dan telah menguasai kosakata dasar dan kalimat dasar (basic sentence) untuk berkomunikasi menggunakan Bahasa Inggris.

\section{DAFTAR PUSTAKA}

Dudley-Evans, T.,dan St. John, M. J. Developments In English For Specific Purposes: A Multi-Disciplinary Approach. Cambridge, England: Cambridge University Press.1998.

Nattinger, J. R. Some Current Trends In Vocabulary Teaching. R. Carter \& M. McCarty (Eds.). Vocabulary and language teaching (1st ed.). New York: Longman. 1988.

Hutchinson, T. and Waters, A. English for Spesific Purposes; a learning-centered Approach, Cambridge: CUP. 1987.

Robinson, P.ESP Today: A Practitioner's Guide Hemel Hempstead. Prentice Hall International. 1991.

Sanjaya, Wina. Strategi Pembelajaran Berorientasi Standar Proses Pendidikan. Jakarta: Prenada Media Group, 201.

Slavin, R.E. Cooperative Learning: Theory, research, and practice (2nd edition). Boston: allyb \& bacon.1995

Solihatin, Etin, Cooperative Learning analisis model pembelajaran IPS, Jakarta:PT Bumi Aksar. 2009.

Suprijono, Agus. Cooperative Learning Teori Dan Aplikasi Paikem, Jokjakarta: PUSTAKA BELAJAR. 2012. 